\title{
SASTRA LISAN SEBAGAI REFLEKSI KEARIFAN LOKAL DALAM MENJAGA SIKAP, PERILAKU, DAN ETIKA
}

\author{
Winarti $^{1}$, Siti Hardiyanti Amri ${ }^{2}$ \\ ${ }^{1}$ IAIN Surakarta, ${ }^{2}$ STKIP Muhammadiyah Barru \\ 1winasalim17@gmail.com, 2sitihardiyantia1@gmail.com
}

\begin{abstract}
Local wisdom has a close relationship with society and culture. Culture is an abstract knowledge that exists in a nation. Through culture, individuals as part of an ethnic group will manifest behaviors patterns to interact with their social environment. In this case, oral literature plays an important role in constructing local wisdom as a part of culture of which function to maintain attitudes, behaviors, and ethics found in social life. All elements involved in local wisdom synergize in upholding norms, values, culture, attitudes, behaviors, and ethics as reflected in the tradition of tabu, myth and folklore, traditional expressions, and traditional ceremonies.
\end{abstract}

Keywords: oral literature, local wisdom, norms, values, society.

\section{PENDAHULUAN}

Sastra lisan merupakan bagian dari budaya Indonesia. Sastra lisan tumbuh dan berkembang dengan baik di Indonesia. Hal ini menyebabkan sastra lisan memiliki peran penting dalam pembentukan kearifan lokal sebagai penjaga sikap, perilaku, dan etika dalam kehidupan masyarakat. Sastra lisan yang ikut berperan dalam pembentukan suatu kearifan lokal tersebut menyangkut kemampuan bertahan terhadap budaya luar, kemampuan mengakomodasi unsur-unsur budaya luar ke dalam kebudayaan asli, dan kemampuan mengendalikan serta memberikan arah pada perkembangan budaya. Kearifan lokal sebagai bagian dari budaya suatu masyarakat dipengaruhi oleh peran sastra lisan yang cukup penting dalam kaitannya sebagai pembentuk kearifan lokal yang berfungsi sebagai penjaga sikap, perilaku, dan etika.

Kearifan lokal memiliki kaitan yang erat dengan masyarakat dan kebudayaan. Kebudayaan merupakan suatu pengetahuan yang bersifat abstrak yang ada pada suatu bangsa. Melalui kebudayaan, individu sebagai bagian dari suatu suku bangsa akan 
mewujudkan pola tingkah laku untuk berinteraksi dengan lingkungan sosialnya. Kebudayaan yang sifatnya abstrak dan berada dalam pikiran individu anggota suatu masyarakat dipakai sebagai sarana interpretasi yang merupakan rangkaian model-model kognitif yang dihadapkan pada lingkungan hidup manusia atau dapat dikatakan sebagai referensi dalam mewujudkan tingkah laku berkenaan dengan pemahaman individu terhadap lingkungan hidupnya (Satyananda dkk., 2013: 8). Sastra lisan yang berperan penting dalam pembentukan kearifan lokal sebagai bagian dari kebudayaan inilah yang berfungsi sebagai penjaga sikap, perilaku, dan etika yang berlaku dalam kehidupan masyarakat. Semua unsur yang terkait dalam suatu kearifan lokal bersinergi dalam menjunjung tinggi norma, budaya, sikap, perilaku, dan etika termasuk pula hal-hal yang berkaitan dengan tradisi pantang larang yang merupakan hasil dari pengetahuan abstrak yang ikut dibentuk oleh sastra lisan sebagai penyampai cerita maupun mitos yang berkembang dalam suatu masyarakat.
Kearifan Lokal, Sikap, Perilaku, dan Etika

Istilah kearifan lokal (local wisdom) terdiri dari dua kata yakni kearifan (wisdom) dan lokal (local). Jika ditelisik dari Kamus Inggris Indonesia John M. Echols dan Hassan Shadily, kata local bermakna setempat dan wisdom bermakna kearifan atau kebijaksanaan. Maka local wisdom (kearifan setempat) dapat dipahami sebagai gagasan-gagasan setempat yang bersifat bijaksana, penuh kearifan, bernilai baik, yang tertanam dan diikuti oleh anggota masyarakatnya. Kearifan lokal merupakan produk budaya yang sudah selayaknya dipertahankan dan menjadi acuan dalam menjalani kehidupan. Bentuk-bentuk kearifan lokal dalam masyarakat dapat berwujud nilai-nilai, norma, etika, kepercayaan, adat-istiadat, hukum adat, dan aturanaturan khusus (Sugianto dkk., 2015: 68). Kearifan lokal sebagai produk budaya berwujud nilai-nilai, norma, etika, kepercayaan, adat istiadat, hukum adat, dan aturan-aturan khusus yang berlaku dalam suatu masyarakat perlu dijunjung tinggi dan dijaga keberlangsungannya karena mengandung pedoman dan nilai-nilai 
kebaikan dalam kehidupan masyarakat.

Kearifan lokal dapat diartikan sebagai nilai-nilai yang berlaku dalam suatu budaya. Masyarakat mengakui kebenaran nilai-nilai tersebut dan menjadi pedoman perilaku mereka. Nilai-nilai yang berlaku ini dianggap sebagai entitas yang sangat menentukan harkat dan martabat manusia dalam hubungan sosial karena di dalamnya terkandung kreatifitas dan pengetahuan lokal yang dimiliki masyarakat. Selain itu, kearifan lokal juga dipandang sebagai perekat di antara warga masyarakat. Secara fungsional, eksistensi kearifan lokal dapat memperkuat sistem budaya sebagai acuan dalam kehidupan masyarakat dan memberi rasa kebersamaan dan persaudaraan bagi sebuah komunitas untuk hidup secara dinamis dan damai (Sulaiman dkk., 2011: 3). Eksistensi kearifan lokal dipandang sebagai suatu hal yang mampu memperkuat sistem budaya sebagai pedoman dalam kehidupan masyarakat sehingga dapat tercapai suatu kehidupan yang dinamis dan damai.

Adapun beberapa fungsi kearifan lokal sebagaimana yang dikemukakan oleh John Haba dalam
Sulaiman dkk (2011: 14) yakni; 1) sebagai penanda identitas sebuah kelompok masyarakat, 2) sebagai kohesi sosial lintas agama, lintas warga, dan kepercayaan, 3) sebagai sebuah unsur kebudayaan yang hidup dalam masyarakat yang tidak bersifat memaksa, 4) sebagai pemberi warna kebersamaan bagi sebuah kelompok masyarakat, 5) pola pikir dan hubungan timbal balik yang berdasar pada kebudayaan, dan 6) mempererat solidaritas dan meningkatkan apresiasi antar individu dalam masyarakat.

Dari beberapa pengertian yang telah dikemukakan sebelumnya, dapat disimpulkan bahwa kearifan lokal merupakan seperangkat pengetahuan dan pandangan yang dimiliki oleh masyarakat setempat yang mengandung filosofi nilai-nilai kehidupan. Nilai-nilai inilah yang kemudian memandu sikap, perilaku, dan etika masyarakat dalam suatu budaya tertentu. Murniatmo dkk (1986: 57) mengemukakan bahwa nilainilai budaya dapat berwujud normanorma, aturan-aturan, adat-istiadat yang berperan sebagai pedoman tingkah laku dan perbuatan manusia. Dengan kata lain, nilai budaya berfungsi sebagai penuntun arah perilaku dan perbuatan 
manusia dalam sebuah sistem sosial yang disebut masyarakat. Nilai - nilai yang dimiliki oleh setiap budaya tentu bersifat relatif. Meskipun universal atau terdapat di setiap komunitas masyarakat tapi setiap budaya berbeda dalam menentukan hal-hal yang dianggap berharga dan penting. Misalnya, sesuatu yang dianggap baik dan benar bagi masyarakat suku Minang belum tentu demikian bagi masyarakat dari suku lain seperti Bugis, Sunda, atau Bali. Seperti yang dipaparkan oleh Utomo dkk (1993: 31), nilai-nilai budaya merupakan seperangkat konsepsi abstrak yang tertanam dalam benak masyarakat terkait hal-hal yang dianggap berharga dan tidak berharga (remeh) dalam sistem kehidupan masyarakat. Seperangkat nilai ini meliputi tatakrama/ sopan santun, kedisiplinan dan tanggung jawab, kerukunan, kemandirian, dan sebagainya. Sikap, perilaku, dan etika merupakan tiga hal yang berkaitan erat dengan tatakrama/ sopan santun yang berlaku dalam suatu masyarakat.

Sikap menurut Berkowitz dalam Nurwanti dkk adalah suatu respon evaluatif yang memberikan kesimpulan nilai terhadap stimulus dalam bentuk positif atau negatif, baik atau buruk, suka atau tidak suka yang kemudian mengkristal sebagi potensi reaksi terhadap obyek. Dengan demikian respon sikap yang dicerminkan dalam bentuk tindakan atau perilaku sebenarnya telah didasari oleh evaluasi dalam diri individu (Nurwanti dkk., 2011: 137). Respon sikap adalah suatu bentuk tindakan yang sebenarnya telah didasari oleh evaluasi dalam diri individu. Dalam hal ini perilaku atau tindakan yang berfungsi sebagai alat untuk meneruskan respon sikap yang ada dalam diri individu sedangkan etika yang menjadi dasar penilaian moral tentang apa yang dianggap benar, salah, baik, atau buruk yang berkaitan dengan nilai-nilai, norma, dan tata krama yang berlaku dalam suatu masyarakat.

\section{Sastra Lisan sebagai Refleksi}

\section{Kearifan Lokal di Beberapa Daerah di Indonesia}

Masyarakat Indonesia terdiri dari ratusan suku bangsa yang masingmasing memiliki kekhasan. Kekhasan inilah yang menjadi ciri yang dimiliki satu suku yang membedakannya dengan suku yang lainnya. Keunikan yang dimiliki setiap suku tercermin dari 
perilaku, baik dalam kehidupan seharihari maupun dalam hubungan antar individu dalam masyarakat (Ayatrohaedi dkk., 1989: 1). Keunikan dan kekhasan yang dimiliki suatu suku menjadi sebuah penanda identitas bagi suku tersebut yang tercermin dalam perilaku di kehidupan mereka seharihari yang terkait dengan hubungan individu dalam kehidupan masyarakat. Beberapa contoh sastra lisan pembentuk kearifan lokal yang berlaku di beberapa daerah di Indonesia dapat dipaparkan melalui tradisi tabu atau pantangan, dongeng dan cerita rakyat, ungkapan tradisional, serta upacara tradisional.

\section{Tabu atau Pantangan}

Pantangan merupakan sesuatu yang dilarang atau tidak boleh dilakukan. Pantangan merupakan aturan tidak tertulis yang sampai dari mulut ke mulut atau diwariskan dari generasi ke generasi (Andayani dkk., 2004: 159160). Penerapan tabu atau pantangan merupakan sarana untuk mengajarkan anggota masyarakat utuk bersikap sebagaimana mestinya dalam suatu pergaulan (Ramlan dkk., 1992: 117). Pantangan-pantangan yang diciptakan masyarakat merupakan bentuk kreatifitas dalam menanamkan nilainilai dalam bersikap dan berperilaku. Adapun fungsi dari penerapan tabu atau pantangan yaitu untuk menjaga etika kesopanan dalam kehidupan masyarakat, seperti yang berlaku di beberapa daerah di nusantara misalnya Sumatera Selatan. Berdasarkan informasi yang diperoleh diperoleh dari masyarakat Kabupaten Bangka, ada beberapa pantangan yang ditanamkan kepada anak-anak sebagai pola dan cara mendidik orang tua seperti larangan bersiul pada waktu maghrib yang konon jika dilakukan makhluk halus akan datang. Namun, menurut masyarakat makna sebenarnya dari tabu ini adalah agar pada waktu pelaksanaan ibadah umat Islam yaitu sholat tidak ada yang bersiul karena dapat mengganggu masyarakat yang sedang menjalankan ibadah. Pantangan lain adalah larangan memanggil orang tua atau yang lebih tua dengan menyebutkan nama saja, tidak diperbolehkan memegang kepala orang tua atau istilah setempat "tunjuk kepala" karena bagi yang melakukan hal ini diyakini akan terkena "tulah atau kuwalat". Larangan ini tentu berhubungan dengan sikap sopansantun dan hormat terhadap yang lebih 
tua (Ramlan dkk., 1992: 114). Sikap sopan-santun ditanamkan untuk membentuk sikap saling menghormati dan menghargai orang lain.

Tabu atau pantangan dengan tujuan untuk menjaga etika kesopanan juga ditemukan di Sumatera Barat. Di dalam kehidupan masyarakat Minangkabau, pantang untuk menyebut nama kepada yang lebih tua dan kewajiban memanggil gelar kepada seseorang yang telah berstatus orang sumando dan seseorang yang telah diangkat Datuk atau Penghulu (kepala suku) (Karim dkk., 1992: 79-81). Pantangan ini dibentuk sebagai penjaga sikap hormat terhadap yang lebih tua sehingga etika kesopanan dapat terus dijaga.

Adapun tabu atau pantangan untuk menjaga etika kesopanan yang berlaku di Jawa Barat atau etnis Sunda antara lain; larangan menduduki nyiru akibatnya bakal mati di perantauan, tidak boleh melangkahi padi (Nyi Sri) akibatnya mendapat penyakit yang disebabkan oleh setan, duduk di pintu akan mengakibatkan lambat jodoh, dan anak-anak tidak boleh lalanggiran (bermain menelungkup, meniarap) akibatnya ditinggal mati oleh ibu
(Mustapa, 1996: 5, 12 dan 13). Mitos tentang pantang-larang tersebut tumbuh dan tersebar di kawasan Jawa Barat. Orang Sunda percaya bahwa larangan/ pantangan tersebut tidak boleh dilanggar jika tidak ingin hal buruk menimpa kehidupan mereka. Jika dipahami lebih mendalam maka pantangan-pantangan tersebut berhubungan dengan etika tentang apa yang dianggap baik ataupun buruk dalam kehidupan masyarakat. Etika tersebut menjadi pedoman bagi sikap dan perilaku yang akan diikuti dan dilakukan oleh masyarakat dalam melakukan suatu hal.

Selain untuk menjaga etika kesopanan dalam kehidupan masyarakat, tabu atau pantangan juga berfungsi untuk menjaga tata krama saat makan, seperti yang ditemukan di beberapa daerah di nusantara. Di Sulawesi Tengah, beberapa aturan tertentu (pantangan) yang harus ditaati oleh anak-anak suku Banggai, khususnya anak-anak desa Lamppio terkait tata krama makan yakni antara lai; tidak boleh makan menggunakan tutup panci karena akan menutup pintu rezeki, tidak boleh makan di muka pintu yang diyakini akan mengeluarkan 
rezeki, tidak boleh makan sambil berjongkok karena dianggap kurang sopan terhadap makanan yang telah membesarkan seseorang, tidak boleh makan di balok melintang karena diyakini jodoh selalu terlangkahi/ lambat mendapat jodoh, tidak boleh makan kepala ikan sebab anak akan bodoh, tidak boleh makan di cukuran kelapa sebab katanya akan ditelan buaya jika berlayar, tidak boleh berkumur dan membuang air kumur di luar rumah sebab akan mati di perantauan, bagi anak perempuan yang belum kawin, pantang mengambil nasi dari belanga langsung dimasukkan kedalam mulut, dan perempuan hamil tidak boleh makan di piring besar (Siodjang dkk., 1993:108). Jika dipahami lebih mendalam, sebenarnya pantangan tersebut berhubungan dengan cara bersikap dan berperilaku saat melaksanakan aktivitas makan sehingga kegiatan makan dengan tujuan untuk memasukkan nutrisi ke dalam tubuh dapat berjalan dengan baik. Hal yang hampir serupa juga berlaku di Sumatera Utara. Ada beberapa pantangan yang berlaku di masyarakat Sumatera Utara misalnya, kalau makan jangan di depan pintu, malu dilihat orang, dan tidak boleh sambil berbicara atau jalan-jalan (Agustrisno dkk., 1994: 48). Pantangan ini tentu berhubungan dengan etika dan tata-krama saat makan. Makan di depan pintu dapat menghalangi orang lain untuk lewat, selain itu berbicara bahkan jalan saat makan dianggap kurang sopan dan tentu saja akan menghambat aktivitas makan itu sendiri karena seseorang mungkin akan tersedak atau terjatuh jika berbicara ataupun berjalan saat makan.

Tabu atau pantangan yang berhubungan dengan tata krama saat makan yang ditemukan pada masyarakat etnis Sunda yaitu tidak boleh membiarkan tempat beras terbuka karena akan mengakibatkan longlongan (berasnya cepat habis diambil setan), larangan memakan nasi langsung dari periuk karena mengakibatkan dimakan harimau, dan larangan makan satu piring berdua karena mengakibatkan dihina orang lain (Mustapa, 1996: 5, 12 dan 13). Larangan membiarkan tempat beras terbuka bisa jadi agar beras tetap terjaga kebersihannya. Sedangkan memakan nasi langsung dari periuk dan satu piring berdua mungkin terkait dengan alasan kesopanan dan juga kesehatan. 
Agak berbeda dengan etnis Sunda, ada beberapa pantangan yang tidak boleh dilakukan oleh masyarakat Bali, yakni antara lain; dilarang berbicara selama makan alasannya orang yang sedang makan menghadapi nasi dan nasi dianggap suci. Pantangan bisa saja bertujuan untuk menjaga tata krama pada saat makan agar kita tidak tersedak maupun batuk karena makan sambil berbicara dapat menyebabkan nasi tersebut keluar dari mulut dan mengenai orang lain bahkan jika secara tidak sengaja nasi tersebut masuk ke dalam saluran pernapasan maka akibatnya akan sangat fatal. Selain itu, terdapat pantangan untuk tidak melempar ciduk nasi ke tempat nasi yang dianggap suci. Bisa jadi pantangan ini dibuat untuk menghindari nasi berserakan di luar tempat nasi karena hal tersebut dianggap sikap boros (Ayatrohaedi dkk., 1989: 32 dan 33). Pantangan atau larangan yang penyebarannya secara turun-temurun dari mulut ke mulut dalam suatu masyarakat sebenarnya tidak serta merta muncul begitu saja tetapi disesuaikan dengan tujuan tertentu misalnya sebagai fungsi pendidikan yang berkaitan erat dengan pelaksanaan etika dalam kehidupan masyarakat.

Selain berfungsi untuk menjaga etika kesopanan dan tata krama saat makan, tabu atau pantang-larang juga berfungsi untuk menjaga kedisiplinan dan keselamatan dalam kehidupan masyarakat. Misalnya, masyarakat kabupaten Sumedang, tepatnya Desa Ujung Jaya memiliki Pantangan yang berlaku dalam lingkungan dapur. Seorang wanita yang sedang memasak di dapur tidak boleh sambil makan atau meninggalkan pekerjaan yang belum selesai. Kalau hal itu dilanggar, maka terkena lolongan atau setan. Sesuatu yang dimakan dianggap tidak membawa berkah atau menimbulkan tenaga karena sari patinya sudah dimakan lolongan atau setan (Andayani dkk., 2004: 159164). Jika dikaji lebih mendalam, pantangan tersebut sebenarnya berhubungan dengan nilai-nilai kedisiplinan yang bertujuan agar kita tidak meninggalkan suatu pekerjaan sebelum kita menuntaskannya karena hal tersebut dapat berakibat pada terhambatnya aktivitas lainnya. Adapun pantangan yang berlaku di masyarakat Sumatera Utara misalnya, jangan mandi-mandi di sungai itu, disana ada hantunya, salah-salah kau bisa 
dimakannya nanti. Pantangan ini merupakan larangan orang tua kepada anaknya demi alasan keselamatan (Agustrisno dkk., 1994: 48). Tradisi pantang-larang yang berlaku ini sebenarnya bertujuan agar anak-anak patuh terhadap nasihat orang tua yang mengharapkan keselamatan bagi anakanaknya dengan menganjurkan untuk menghindari hal-hal berbahaya yang ada di sekitar mereka. Dalam hal ini, mitos yang berhubungan dengan larangan tersebut berfungsi sebagai sarana edukasi dari orang tua terhadap anak-anaknya untuk dapat menjadi suatu pedoman dalam bersikap dan bertingkah laku.

Fungsi lainnya dari tabu atau pantang-larang yaitu untuk menjaga keharmonisan hubungan keluarga. Di Sumatera Barat,ada beberapa pantangan yang berlaku, yaitu; mandi bersama orang sumando (orang semenda) lakilaki. Anak laki-laki yang sudah baligh dilarang mandi bersama dengan orang sumando sebab hubungan orang sumando dengan ipar-iparnya terjalin dalam bentuk segan-menyegani, hargamenghargai, hormat-menghormati, dan tidak terjadi keleluasaan dalam pergaulan. Jika terjadi pencampurbauran mandi bersama ipar, akan hilang batas-batas seganmenyegani antara ipar dengan orang sumando, dan pantang untuk nikah lebih dahulu dari kakak karena hal tersebut dianggap melangkahi sang kakak yang membuat sikap tenggang rasa menjadi terlalaikan, sehingga dapat mengganggu keharmonisan hubungan antar adik dan kakak (Karim dkk., 1992: 79-81). Pantangan ini berhubungan erat dengan penjagaan etika dan batasan tertentu dalam pergaulan keluarga dan bagaimana bersikap terhadap orang yang lebih tua sehingga keharmonisan hubungan antar anggota keluarga dapat terjalin dengan baik.

\section{Dongeng dan Cerita Rakyat}

Dongeng dan cerita rakyat juga merupakan sarana pembentuk karakter, sikap dan perilaku masyarakat. Dongeng bertujuan mendidik atau membina anak-anak. Melalui penceritaan dongeng, anak-anak diharapkan dapat lebih mudah mendengarkan dan mematuhi nasehat orang tua. Seseorang dapat bercermin dari tokoh-tokoh baik yang dikisahkan dalam dongeng. Dongeng menjadi 
cerita yang menggambarkan bahwa dalam kehidupan ini yang benar pasti akan selalu menang menghadapi yang salah (Ramlan dkk., 1992: 114 dan 117). Terkait dengan fungsi dongeng dan cerita rakyat yang mengandung unsur yang mendidik dalam kehidupan masyarakat maka dongeng maupun cerita rakyat tetap terjaga eksistensinya dengan penyebarannya secara lisan. Adapun salah satu fungsi dari dongeng dan cerita rakyat yaitu untuk menjaga bakti dan kasih sayang kepada orang tua, seperti pada beberapa cerita rakyat yang berasal dari beberapa daerah di Indonesia.

Cerita rakyat yang paling digemari oleh penduduk di Kabupaten Bangka adalah cerita "Tujuh Beradik". Cerita ini menceritakan tentang seorang saudagar yag memiliki tujuh orang putra-putri. Pada suatu hari, saudagar bertanya kepada anak-anaknya: "apa yang kamu inginkan bila aku sudah mati?". Jawaban ketujuh anaknya pun bermacam-macam, ada yang menginginkan tanah, sawah, rumah, kebun dan lain-lain. Berbeda dari keenam saudaranya, si bungsu mengatakan dia tidak menginginkan apa-apa, yang diinginkan hanyalah peci ayahnya. Ayahnya bertanya: "Mengapa engkau menginginkan peci ini?" $\mathrm{Si}$ anak menjawab, bahwa pecilah yang tetap berada di atas kepala orang tuanya. Hal ini akan mengingatkan dia agar selalu berdoa untuk orang tuanya (Ramlan dkk., 1992: 114-115). Cerita rakyat yang pada umumnya menyebar secara lisan mengandung unsur pendidikan yang berfungsi sebagai pedoman kepada anak untuk berbakti dan menyayangi kedua orang tua.

Cerita rakyat lainnya berasal dari Sumatera Barat yang umumnya dikenal oleh suku Minangkabau sebagai cerita Rambun Pamenan dan Malin Kundang Anak Durhaka. Keduanya memiliki kandungan cerita yang berbeda. Rambun Pamenan menceritakan tentang seorang anak yang berbakti kepada ibunya dengan menyelamatkan ibunya dari seorang Raja yang kejam bernama Rajo Angek Garang. Jika dalam Rambun Pamenan yang ditonjolkan adalah sikap kepahlawanan seorang anak, Malin Kundang justru menceritakan sikap seorang anak yang durhaka pada ibunya. Meskipun kedua cerita tersebut berbeda, cerita tersebut mengandung pesan moral akan pentingnya 
pengabdian dan kasih sayang kepada ibu. Rambun Pamenan menggambarkan anak yang penuh pengabdian kepada orang tua, sedangkan Malin Kundang melambangkan anak yang tidak mengabdi kepada orang tua yang akhirnya berakibat kehancuran dirinya (Karim dkk., 1992: 82). Kedua kisah tersebut mengarah pada satu nasihat inti bahwa seorang anak harus berbakti kepada orang tuanya. Nasihat tentang kasih sayang dan bakti kepada orang tua tersebut tersirat dalam cerita rakyat Rambun Pamenan dan Malin Kundang yang sampai saat ini masih diceritakan secara turun-temurun dari mulut ke mulut.

Fungsi lain dari dongeng dan cerita rakyat adalah untuk memperkuat dan menjaga nilai-nilai kerukunan seperti yang dikisahkan dalam salah satu dongeng yang sering diceritakan di wilayah Jawa Tengah, yaitu dongeng tentang asal muasal binatang "uwauwa" (orang hutan). Dongeng ini menceritakan tentang dua anak laki-laki bersaudara, anak tertua selalu nakal pada adiknya dan tidak pernah menurut pada orang tuanya. Akhirnya anak nakal tersebut dibawah ke hutan oleh Pak Dhenya (di Banyumas Pak Dhe merujuk ke "uwa"). Si anak kemudian ditinggalkan sendiri di dalam hutan dengan hanya berbekal nasi di dalam tabung. Anak tersebut memanggilmanggil Pak Dhenya dengan sebutan "uwa-uwa" sambil menangis tersedusedu. Akhirnya anak tersebut berubah menjadi binatang "uwa-uwa" (orang hutan). Sebagai penutup cerita, orang tua akan mengakhiri dengan pesan yang berbunyi Mulane ya Cah, aja sok nakal karo sedulure dhewek, mengko nek nakal dadi uwa-uwa yang artinya makanya jangan nakal Nak, jangan suka nakal sama saudara sendiri, nanti kalau nakal menjadi orang hutan. Orang tua menanamkan nilai-nilai kerukunan kepada anak melalui cerita-cerita menakutkan. Dongeng ini mengandung pesan pentingnya hidup rukun antar saudara kandung (Prawironoto dkk., 1994: 73-74). Sastra lisan dalam bentuk dongeng yang diceritakan secara turuntemurun dari orang tua kepada anaknya menjadi suatu sarana untuk menanamkan nilai-nilai kebaikan, salah satunya tentang pentingnya kerukunan terutama antar saudara kandung.

\section{Ungkapan Tradisional}

Ungkapan tradisional juga 
seringkali digunakan sebagai sarana untuk mendidik anak-anak. Ungkapanungkapan tersebut menjadi falsafah nilai-nilai yang membentuk sikap dan perilaku seseorang. Ungkapan tradisional merupakan bahasa metaforik yang mengungkapkan isi dan pikiran dan perasaan. Didalamnya terkandung nilai-nilai sosial budaya yang perlu diselami dan direnungkan sebagai pedoman tingkah laku (Ramlan dkk., 1992: 118). Adapun Fungsi dari ungkapan tradisional yaitu untuk menjaga nilai-nilai keagamaan, seperti yang berlaku di Jawa Tengah. Bagi masyarakat Jawa Tengah, khususnya warga Pekuncen, ungkapan-ungkapan merupakan sarana penyampaian pesan, petuah, dan nasihat yang menjadi pedoman dalam berperilaku. Ungkapan tersebut bisa mengandung nasihat kerukunan, kesetiaan, kedisiplinan, tanggung jawab, kemandirian, dan nilai agama. Contoh ungkapan yang mengandung nilai kesetiaan dan nilai keagamaan antara yakni aja lali marang asale yang berarti bahwa seseorang hendaknya senantiasa ingat akan asalusul dan tidak lupa daratan. Ungkapan ini mengandung ajaran agar seseorang pada saat tertentu mencapai titik kebahagiaan, hendaknya selalu tawakal dan ingat bahwa dirinya adalah makhluk Tuhan. Melalui ungkapan ini, seseorang diharapkan menyadari pentingnya keterikatan kepada tanah air dan tanah tumpah darah sebagai tempat kelahiran (Prawironoto dkk., 1994:79). Ungkapan tersebut mengandung pesan moral bahwa hendaknya manusia tidak melupakan asal-usulnya sebagai makhluk ciptaan Tuhan yang wajib menyembah dan bersyukur kepadaNya. Sebagai makhluk ciptaan Tuhan kita juga tidak diperkenankan untuk menjadi orang yang sombong dan melupakan nilai-nilai keagamaan.

$$
\text { Masyarakat Jawa pada }
$$
umumnya memegang sebuah konsep sentral yang disebut "mampir ngombe" yang artinya singgah untuk minum. Orang Jawa mengibaratkan bahwa hidup di dunia ini ibaratnya seorang yang sedang dalam perjalanan pulang menuju alam sejati. Selama mampir ngombe di dunia ini, orang harus bersikap rela (rila) yang dimaknai sikap ikhlas disertai rasa bahagia dalam menyerahkan segala hak-haknya dan semua hasil kerjanya kepada Tuhan. Selanjutnya bersikap menerima (narima) dengan riang hati segala 
sesuatu yang menimpa dirinya. Narima adalah perasaan puas dengan nasibnya, tidak memberontak, menerima dengan penuh rasa syukur. Dan sikap yang terakhir adalah Sabar yang dimaknai sebagai sikap rela hati menyerahkan diri dengan sikap menerima senang hati dan bersikap bijaksana. Kesabaran dianggap kelapangan dada yang dapat merangkul segala pertentangan. Tiga sikap yang telah dikemukakan sebelumnya merupakan konsep dasar yang terdapat dalam pandangan dunia orang Jawa baik priyayi maupung abangan. Tata krama masyarakat Jawa lahir dan bersumber dari sikap-sikap hidup tersebut (Ayatrohaedi dkk., 1989: 136137).

Sementara itu, di Sumatera Selatan, ungkapan tradisional yang masih sering digunakan masyarakat setempat adalah antu kidung, ki janen ngelangkahku, ki mati dulu, ko mati dudi, nu langit tujuh lapis artinya jangan sombong dengan ilmu pengetahuan yang sedikit, karena masih banyak orang yang jauh lebih pandai dari kita (Ramlan dkk., 1992: 115). Ungkapan tersebut sebagai pengingat bagi semua orang untuk terus belajar dan jangan pernah merasa sombong atas kepandaian yang dimiliki.

Fungsi lain dari ungkapan tradisional adalah untuk menjaga nilainilai moral, sebagai contoh yaitu ungkapan yang berasal dari Sumatera Barat. Adapun beberapa ungkapan masyarakat Sumatera Barat yang mengandung nilai-nilai kehidupan yakni antara lain; sekali lancung ke ujian selama hidup orang tidak percaya yang artinya jangan sekali-kali berbuat dusta, akibatnya orang tidak mempercayai kita, air tulang bubungan jatuhnya ke cucuran atap maksudnya perilaku orang tua akan ditiru anak oleh sebab itu setiap orang tua harus berperilaku baik untuk dicontoh oleh anak-anak mereka, tegang bajelo-jelo, kandua badantiangdantiang (tegang berjela-jela, kendur berdenting-denting) maksudnya dalam menyelesaikan suatu masalah harus ada tolak angsur/ tenggang rasa, kareh ditakiak, lunak disudu (keras ditakik, lunak disudu) maksudnya dalam bersikap jangan keras dan jangan pula lunak, jadi pertengahan saja, anak dipangku, kemenakan dibimbing, orang kampung patenggakan, jago nagari jan binaso (anak dipangku, kemenakan dibimbing, orang kampung pertenggakan, jaga negeri jangan 
binasa). Pepatah ini berisi pesan agar terjalin kerukunan dalam pergaulan hidup (Karim dkk., 1992: 83-84).

Sementara itu, di wilayah Sulawesi Selatan, etnis Bugis memegang teguh nilai-nilai siri' dalam kehidupan. Siri' bermakna mengedepankan martabat dan harga diri atas segalanya. Siri' bisa juga diartikan sebagai daya pendorong untuk melenyapkan (membunuh) atau mengasingkan jika ada yang merendahkan martabat atau membuat masyarakat dari suku bugis tersinggung. Selain itu, siri' dapat pula dipandang sebagai pendorong utuk bekerja keras bagi suatu usaha. Ada beberapa ungkapan untuk memahami konsep siri' yakni sebagai berikut; siri' emmi ri onroang rilino yang artinya hanya siri' kita hidup di dunia. Dalam ungkapan ini termaktub arti siri' sebagai hal yang memberi identitas sosial dan martabat kepada seseorang. Hidup baru ada artinya hanya jika martabat atau harga diri ada. Selanjutnya ungkapan, mate $r i$ siri'na yang artinya mati dalam siri' atau mati untuk menegakkan martabat/harga diri. Mati yang demikian dianggap sesuatu yang terpuji dan terhormat. Kemudian ungkapan mate siri' yang artinya orang yang telah kehilangan martabat/harga dirinya adalah bangkai hidup. Orang bugis yang merasa mate siri' akan melakukan jallo (amul) hingga ia mati sendiri karena dengan demikian disebut napetetton ngi siri'na artinya menegakkan kembali martabat dirinya (Ayatrohaedi dkk., 1989: 102-103). Dalam hal ini terlihat sangat jelas bahwa martabat atau harga diri adalah sesuatu yang sangat penting dalam kehidupan masyarakat bugis. Prinsip kehidupan ini kemudian membentuk karakter masyarakat suku bugis yang senantiasa berani, bekerja keras, dan pantang menyerah.

Selanjutnya, fungsi dari ungkapan tradisional yaitu untuk menjaga alam dan kebersihan lingkungan, misalnya ungkapanungkapan yang digunakan oleh masyarakat kabupaten Bangka yakni antara lain; jangen mueng keremek telo di ae laut, nanti kesurup, artinya jangan membuang sampah ke air laut nanti kemasukan roh jahat. Ungkapan ini bermakna sikap yang harus dimiliki setiap orang untuk menjaga kebersihan lingkungan karena alam sebagai tempat tinggal kita harus tetap dijaga kebersihannya sehingga keseimbangan 
dan kebaikan alam bisa kita nikmati selamanya (Ramlan dkk., 1992: 115).

\section{Upacara Tradisional}

Upacara tradisional juga memiliki peranan yang penting dalam penanaman nilai-nilai keagamaan, kebersamaan, kerukunan, dan gotong royong. Salah satu masyarakat yang masih menjalani upacara adat sebagai bagian dari kebudayaannya adalah masyarakat Jawa Tengah yang termasuk dalam etnis Jawa. Ada sebuah upacara tradisional di desa Pekuncen yang mengandung nilai keagamaan yakni upacara "unggah-unggahan". Upacara ini erat kaitannya dengan kepercayaan masyarakat setempat bahwa selama bulan suci Ramadhan, arwah orang yang telah meninggal akan dibebaskan dari siksaan kubur. Sehingga upacara ini dimaksudkan untuk "ngunggahna" atau mengantar arwah yang berada di alam kubur untuk naik ke suatu tempat yang terbebas dari siksa kubur. Tujuan yang terpenting dari upacara ini adalah membersihkan jiwa dan raga selama menjelang pelaksanaan ibadah puasa. Sebagi akhir upacara ini adalah jabat tangan antar peserta dan selamatan berupa makan bersama sambil beramah tamah.

Selain itu, ada juga yang disebut dengan upacara "sadranan" yang diawali dengan membersihkan kompleks Makam Dawuhan yang dilaksanakan seminggu sebelum acara selamatan "sadranan". Setelah makam bersih, seminggu setelahnya diadakan upacara inti yakni upacara selamatan "sadranan" berupa mendoakan arwah leluhur secara bersama-sama dan diakhiri dengan makan nasi tumpeng bersama. Setelah acara selamatan selesai diadakan pembagian baju pantas pakai untuk warga Desa Dawuhan.

$$
\text { Makna pelaksanaan upacara- }
$$
upacara tradisional yang masih kental dilakukan masyarakat abangan (kejawen) tersebut merupakan sarana bagi masyarakat untuk menumbuhkan sikap kebersamaan, kerukunan, gotong royong, dan saling tolong menolong. Dalam pelaksanaan upacara tesebut, ada nilai silaturrahmi yang dijalin antar warga, gerakan kebersihan yang dilakukan bersama. Nilai-nilai kebersamaan tersebut sangat bermanfaat dalam menjalin ikatan sosial yang akan membentuk jiwa persatuan dan kesatuan (Prawironoto dkk., 1994: 6973). Upacara tradisional tersebut tetap 
dilaksanakan sampai saat ini sebagai bagian dari kebudayaan yang berkaitan dengan kearifan lokal sebagai penjaga sikap, perilaku, dan etika dalam kehidupan masyarakat. Upacara tradisional tersebut juga berfungsi sebagai penjaga kerukunan dan nilai kebersamaan/ gotong-royong masyarakat yang menjalankannya.

\section{PENUTUP}

Sastra lisan memiliki peran yang cukup penting dalam terbentuknya kearifan lokal sebagai penjaga sikap, perilaku, dan etika dalam kehidupan masyarakat. Mitos tentang pantanglarang, dongeng dan cerita rakyat, ungkapan tradisional, serta upacara tradisional merupakan bentuk dari kearifan lokal yang ikut dibentuk oleh sastra lisan yang penyebarannya secara turun-temurun dari mulut ke mulut dalam suatu masyarakat. Ada fungsifungsi dan tujuan-tujuan tertentu yang ingin dicapai mengapa suatu hal tidak boleh dilakukan karena dianggap sebagai suatu pantangan atau hal yang dianggap tabu untuk dilakukan. Peran sastra lisan dalam hal ini yaitu sebagai penyampai kisah tentang apa yang sebaiknya dilakukan dan apa yang tidak boleh dilakukan. Apa yang tidak boleh dilakukan atau yang disebut dengan pantangan harus dihindari karena jika dilakukan maka akan mendatangkan keburukan bagi yang melakukannya. Dalam hal ini sastra lisan yang berupa mitos pantang-larang berfungsi sebagai penjaga sikap, perilaku, dan etika dalam kehidupan masyarakat. Fungsi yang hampir sama juga dimiliki oleh dongeng dan cerita rakyat yang berkembang di beberapa daerah yang juga berisi pesan tentang pentingnya penjagaan atas sikap, perilaku, dan etika. Bahkan ungkapan tradisional serta upacara tradisional juga memiliki pesan khusus yang ingin disampaikan kepada masyarakat yaitu tentang nilai-nilai kebaikan yang harus terus dijaga dan dipertahankan keberlangsungannya dalam kehidupan masyarakat sehingga dapat dicapai suatu kehidupan yang dinamis. Fungsi yang tersirat dalam sastra lisan dalam konteks kearifan lokal sebagai penjaga sikap, perilaku, dan etika adalah fungsi yang bersifat mendidik dan membina masyarakat, bahwa ada hal-hal yang tidak patut dilakukan dan sebaiknya dihindari demi kebaikan diri kita sendiri serta orang lain. Pesan tersirat dalam sastra lisan 
mengandung nilai-nilai kebaikan, norma dan adat istiadat dalam suatu masyarakat sehingga membentuk kearifan lokal yang dapat digunakan sebagai suatu pedoman untuk mejalani kehidupan masyarakat dalam bersikap dan berperilaku.

\section{DAFTAR PUSTAKA}

Agustrisno, Simanjuntak, Junjungan S.B.P., Rachman, Abdul, dan Sinegar, Edi Saputra, 1994, Pembinaan Budaya Dalam Lingkungan Keluarga Daerah Sumatera Utara, Sumatera Utara: Departemen Pendidikan dan Kebudayaan.

Andayani S., Ria, Rosyadi, Harsono, Dibyo T., Alamsyah P., Suwardi, Herlinawati, Lina, dan Sucipto, Toto, 2004, Kehidupan Sosial Budaya Masyarakat Desa Ujung Jaya Kabupaten Sumedang, Bandung: Kementrian Kebudayaan dan Pariwisata.

Ayatrohaedi,Warnaen, Suwarsih, Manan, Fadjria Novari, Utomo, Sri Saadah, dan Sastrosuwondo, Sumantri, 1989, Tatakrama di Beberapa Daerah di Indonesia, Jakarta: Departemen Pendidikan dan Kebudayaan.

Karim, A., Delly, H.S.M., Rusdi, dan Dini Amir, 1992, Pembinaan Budaya dalam Lingkungan Keluarga di Daerah Sumatera Barat, Sumatera Barat: Departemen Pendidikan dan Kebudayaan.
Murniatmo, Gatut, Suratmin, Moertjipto, dan Salamun D., 1986, Kehidupan Sosial Budaya Orang Naga, Salawu, Tasikmalaya Jawa Barat, Jawa Barat: Departemen Pendidikan dan Kebudayaan.

Mustapa, R.H. Hasan, 1996, Adat Istiadat Sunda, Bandung: Alumni.

Nurwanti, Yustina H., Susilantini, Endah, Herawati, Isni, dan Suwarno, 2011, Kajian Sosial, Budaya, dan Ekonomi Masyarakat di Kawasan Situs Sangiran, Yogyakarta: Balai Pelestarian Nilai Budaya.

Prawironoto, Hartati, Suyatno W., Sumardi, dan Santoso, Djarot, 1994, Pembinaan Budaya dalam Lingkungan Keluarga di daerah Jawa Tengah, Jawa Tengah: Departemen Pendidikan dan Kebudayaan.

Ramlan, Eddy dan Idrajaya, Yenny Heryani, 1992, Pembinaan Budaya dalam Lingkungan Keluarga Daerah Sumatera Selatan, Sumatera Selatan: Departemen Pendidikan dan Kebudayaan.

Satyananda, I Made, Sanjaya, I Putu Kamasan, Dwikayana, Kadek, dan Nitbani, Semuel H., 2013, Kearifan Lokal Suku Helong di Pulau Semau Kabupaten Kupang Nusa Tenggara Timur, Yogyakarta: Balai Pelestarian Nilai Budaya Bali.

Siodjang, Baso, Tadorante, Usuluddin, dan Tahawila, Amir, 1993, 


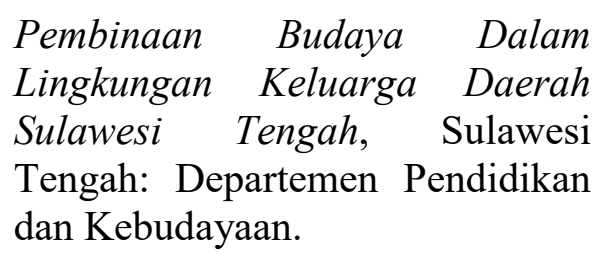

Sugianto, Ida Bagus, Ariani, Ni Luh, dan Santosa, Bambang, 2015, Kearifan Lokal Masyarakat Nelayan Tanjung Luar Lombok Timur, Nusa Tengara Barat, Yogyakarta: Kepel Press.

Sulaiman, Fauzi, Romzan, Sodli, Ahmad, dan A.R, Dahlan, 2011, Menguak Makna Kearifan Lokal Pada Masyarakat Multikultural, Semarang: Robar Bersama.

Utomo, Muhajir, Budiyono, Djausal, Ansori, dan Rosra, Muswardi, 1993, Pembinaan Budaya dalam Lingkungan Keluarga di Daerah Lampung, Lampung: Departemen Pendidikan dan Kebudayaan. 